\title{
Setting the Terms of State Intervention: Employers, Unions and the Politics of Inclusiveness in Austrian and Danish Vocational Education Institutions
}

\begin{abstract}
How do coalitional dynamics matter for the capacity of states to maintain social inclusion in coordinated models of capitalism? Taking its departure in scholarship emphasizing the influence of employers on the extent of state intervention in post-industrial economies, this paper argues that employer influence depends on which actors they team up with - unions or parties. If unions depend on employers for their organizational influence in a policy field, unions become a strong coalitional partner for employers in weakening demands for inclusiveness from the parliamentary arena. Conversely, if unions have influence independent of any coalition with employers, both unions and employers are likely to team up with political parties they share preferences with. This makes the level of inclusion resulting from increased state intervention more fluctuating, depending on who holds government power. A comparative study of reforms of Danish and Austrian vocational education institutions corroborates the empirical purchase of the argument.
\end{abstract}

Martin B. Carstensen

Roskilde University

Department of Social Science and Business

Universitetsvej 1

4000 Roskilde, Denmark

mcar@ruc.dk

Patrick Emmenegger

University of St. Gallen

School of Economics and Political Science

Müller-Friedberg-Strasse 8

9000 St. Gallen, Switzerland

patrick.emmenegger@unisg.ch

Daniel F. Unterweger

University of St. Gallen

School of Economics and Political Science

Müller-Friedberg-Strasse 8

9000 St. Gallen, Switzerland

daniel.unterweger@unisg.ch 